\title{
Citra Majapahit dalam Perbandingan Babad dan Kakawin
}

\section{Bambang Soelistyanto}

Keywords: jurnal, berkala, majapahit, literature, philology

\section{How to Cite:}

Soelistyanto, B. Citra Majapahit dalam Perbandingan Babad dan Kakawin. Berkala Arkeologi, 14(1), 7-15. https://doi.org/10.30883/jba.v14i1.625

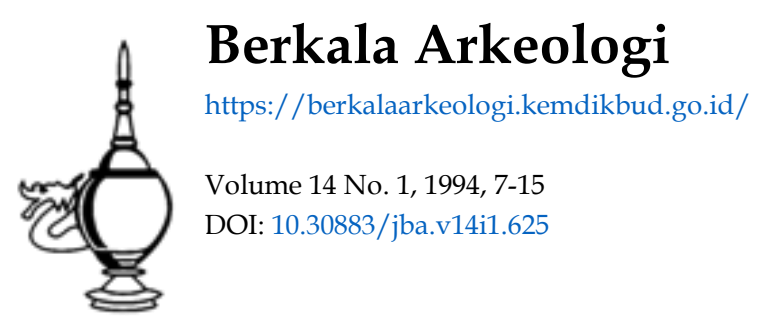

\section{(c) (1) (2)(2)}

This work is licensed under a Creative Commons Attribution-NonCommercial-ShareAlike 4.0 International License. 


\title{
CITRA MAJAPAHIT \\ DALAM PERBANDINGAN BABAD DAN KAKAWIN*
}

\author{
Bambang Sulistyanto \\ (Balai Arkeologi Yogyakarta)
}

Para ahli selama ini beranggapan bahwa di antara sekian banyak kerajaan kuna di indonesia, Majapahit adalah yang paling kuat meninggalkan kenangan dalam masyarakat masa sekarang ini. Kerajaan terakhir dari negara tradisional Hindhu-Jawa ini, tercatat berhasil sepenuhnya menegakkan kesatuan politik dalam suatu wilayah yang luas dan belum pernah terjadi pada masa sebelumnya. 1

Dalam masa kejayaan Majapahit inilah banyak bermunculan karya sastra bermutu. Karya sastra yang diciptakan oleh para seniman bukanlah sekadar untuk dinikmati, tetapi juga dipahami sekaligus dimanfaatkan oleh masyarakat luas pendukungnya. Seniman atau pujangga itu sendiri adalah anggota masyarakat, sehingga hasil karya tersebut mencerminkan kehidupan pada masa itu yang mencakup hubungan masyarakat dengan orang per orang dan juga antar peristiwa-peristiwa yang terjadi dalam batin manusia. Dengan demikian peristiwa yang terekam oleh seorang seniman dan selanjutnya tervisualisasikan dalam bentuk karya sastra tersebut, adalah hasil interaksi antara seniman atau pujangga dengan lingkungan masyarakat sekitarnya (Darmono, 1979:1-6).

Meskipun penelitian terbaru membuktikan, bahwa tidak semua karya sastra menjadi cermin utuh keadaan masyarakat sezaman, namun setidaknya dari ungkapan yang disampaikan dalam karya tersebut dapat dijadikan petunjuk keadaan dan situasi masyarakat pada masa itu. Zoetmulder dalam penelitiannya tentang berbagai Kakawin Jawa kuna telah berhasil membuktikan, bahwa sekalipun cerita-cerita yang terkandung di dalam kitab-kitab tersebut berupa rekaan, namun hasil susastra itu mendekati suatu kenyataan historis (Zoetmulder, 1983:239).

Kakawin Nagarakrtagama hasil karya Prapanca di tahun 1365 M., dapat dijadikan contoh sebuah karya gabungan antara sastra dan sejarah yang banyak diteliti para ahli guna memahami berbagai aspek

Pernah disajikan dalam Rapat Analisis Sumber Tertulis Masa Klasik, di Tromulan, tgl. 18 - 23 November 1991 
kehidupan Majapahit. Dalam Kakawin Nagarakrtagama disajikan data yang cukup lengkap tentang keagungan Majapahit. Tetapi jika citra Majapahit yang demikian gemilang menurut Prapanca itu dibandingkan dengan penulis Babad Tanah Jawi, mungkin akan memberikan kesan yang lain. Dalam Babad Tanah Jawi ditampilkan citra yang sebaliknya, yaitu digambarkan bahwa Kerajaan Majapahit lebih kecil dan suram. Hal tersebut berlawanan dengan gambaran yang diungkapkan oleh Prapanca sekitar tiga abad sebelum penulisan Babad Tanah Jawi.

Tulisan ini bertujuan untuk membandingkan antara citra Majapahit menurut versi Nagarakrtagama dengan citra Majapahit versi Babad Tanah Jawi. Alasan pemilihan Kakawin Nagarakrtagama, karena kakawin ini dipandang sebagai satu-satunya sumber terlengkap dan akurat sebagai sumber sejarah Majapahit, selain itu penulisnya hidup pada zaman tersebut. Adapun Babad Tanah Jawi dipergunakan sebagai pembanding, sebab karya ini muncul pada masa kemudian yang secara kronologis merupakan karya pertama tentang Majapahit di Mataram, Jawa Tengah. Dengan demikian perbandingan kedua sumber yang memiliki perbedaan ruang dan waktu dimaksud untuk mengetahui penilaian kerajaan di Jawa Tengah terhadap Kerajaan Majapahit yang berkembang tiga abad sebelumnya.

\section{II}

Masa kejayaan Majapahit yaitu pada pemerintahan Rajasanagara abad XIV M., dalam Nagarakrtagama diberitakan luasnya pengaruh kekuasaan raja.2 Pengaruh kekuasaan Majapahit ini meliputi hampir seluas wilayah Negara Indonesia sekarang. Bahkan saat itu pengaruh kekuasaan kerajaan ini meluas sampai ke negara-negara tetangga di Asia Tenggara dalam bentuk persahabatan. 3

Sejak ditemukan dan kemudian diterbitkannya Nagarakrtagama, anggapan tentang Majapahit berubah secara radikal. Hal tersebut disebabkan Prapanca sangat pandai menyajikan suasana keagungan dan kemakmuran. Berulangkali ditemukan penyebutan Nusantara dan "dwipantara" atau hanya "desantara', yang semuanya berada di bawah lindungan kekuasaan Majapahit.4

Nagarakrtagama mencatat secara rinci daftar kunjungan tahunan yang dilakukan Rajasanagara ke berbagai daerah di Pulau Jawa, namun tidak disebut-sebut kunjungan raja ke Nusantara. Nusantara sendiri terdiri atas kurang lebih seratus negeri. Hal tersebut memberikan 
kesan, meskipun Jawa dan Nusantara 'tunduk" kepada penguasa Majapahit, namun mereka tetap merupakan dua dunia yang terpisah. Hal itu membuktikan, bahwa negeri-negeri yang dikenal dan dikatakan Prapanca sebagai daerah kekuasaan Majapahit, nampaknya tidak lebih dari suatu daftar nama geografis yang dikenal secara kabur.

Menyimak versi Babad Tanah Jawi tentang Majapahit, apa yang diungkapkan dalam Negarakrtagama nampak lain. Babad Tanah Jawi yang anonim ini berlatar belakang jauh dari ruang maupun waktu dari keberadaan Majapahit. Babad ini merupakan laporan paling awal tentang Majapahit di Mataram, Jawa Tengah yang ditulis sekitar pertengahan pertama abad ke-17 M.5

Dalam versi Babad Tanah Jawi, kebesaran yang dimiliki Majapahit tidak begitu besar, sebagaimana yang dipaparkan Prapanca dalam Nagarakrtagama. Gambaran yang disajikan Babad Tanah Jawi terlihat sangat suram dan kerdil. Raja Majapahit menurut versi Nagarakrtagama dikatakan sebagai manusia super, titisan dewa yang tak pernah alpa memperhatikan dan mengurus rakyatnya; manusia dalam kemuncak daya hidup penuh kekuatan dan semangat yang selalu bergerak mendatangi tempat-tempat suci leluhur, serta mengunjungi berbagai daerah yang menjadi kekuasaannya. Kerajaan pun dilukiskan serupa, memiliki kekuasaan yang besar: makmur, kehidupan jalanan yang riuh dan semarak, serta semua rakyat patuh menyambut gembira setiap kali raja datang dengan rombongannya. Versi Babad Tanah Jawi dalam mengungkapkan para raja Majapahit, terlihat sebaliknya, yaitu tidak memiliki kekuatan dan semangat hidup. Bahkan Raja Majapahit terakhir diungkapkan memiliki perilaku kurang baik, karena menderita penyakit Raja Singa (Olthof, 1941:23).

Adapun mengenai kekuasaan kerajaan, Nagarakrtagama secara jelas mengisahkan, bahwa setelah keberhasilannya menyerang Pajajaran, seluruh Pulau Jawa tunduk kepada Majapahit. Perihal sejumlah sembilan puluh negeri di Nusantara yang menurut Prapanca mencari perlindungan kepada Majapahit, ternyata hanya satu saja yaitu Palembang yang disebutkan oleh Babad Tanah Jawi sebagai negeri taklukan Majapahit.

Masalah Negeri Wandan yang juga terdapat dalam daftar Prapanca (Nag., XIV:5) sebagai daerah bawahan Majapahit, dalam Babad Tanah Jawi hanya disebutkan sebagai tempat gadis budak yang berhasil menyembuhkan penyakit kelamin raja Bra Wijaya dan tidak ada petunjuk bahwa Wandan sebagai daerah taklukan. Sebetulnya, 
gadis Wandan yang dibawa ke Majapahit itu adalah putri raja Campa. Negeri Campa inilah satu-satunya negeri asing yang disebut dalam Babad Tanah Jawi di antara sembilah negara tetangga yang menurut Prapanca bersikap bersahabat dengan Majapahit. Dengan demikian tampak jelas, bahwa citra Majapahit menurut versi Babad Tanah Jawi jauh lebih kecil dibanding dengan citra yang dipersembahkan Prapanca sekitar tiga abad sebelumnya.

Sepeninggal Raja Hayumwuruk dan Patih Gadjah Mada, kerajaan ini mulai memperlihatkan gejala kesuramannya. Menurut penulis Babad Tanah Jawi puncak dari kesuraman tersebut terjadi pada masa pemerintahan Bra-wijaya dengan wilayah kekuasaan tidak lebih dari daerah Jawa Timur. Tentang faktor penyebab kerapuhan Majapahit sudah banyak dikaji para ahli, di antaranya akibat perebutan kekuasaan dan pertentangan keluarga mengenai hak waris. Selain itu kesuraman tersebut juga diakibatkan oleh munculnya persekutuan Islam di sepanjang Pantai Utara Jawa. Persekutuan Islam itu di antaranya terdapat di kota-kota dekat pusat Kerajaan Majapahit. Selanjutnya mereka bertindak sendiri-sendiri menentang Majapahit hingga berangsurangsur runtuh (Hasan Djafar, 1978:45-51).

Secara singkat dapat dijelaskan bahwa Majapahit jauh dari tampilan suatu peta kerajaan yang agung dan besar, melainkan suatu kerajaan yang suram dengan seorang raja yang lemah dan sakit.

III

Karya sastra adalah cermin masyarakat pendukungnya. Sebagaimana telah disinggung di depan, sejak penemuan Nagarakrtagama, gambaran Majapahit berubah secara radikal. Hal tersebut disebabkan dalam kakawin ini diuraikan tentang masa kemegahan Majapahit, namun tidak menyinggung tentang keruntuhan kerajaan tersebut yang terjadi lebih dari se-abad setelah kakawin selasai ditulis. Hal tersebut berbeda dengan sumber Babad Tanah Jawi yang dibuat pada masa Mataram abad XVI-XVII M.

Dari segi kredibilitas, tentu ada kecenderungan untuk lebih mempercayai sumber Nagarakrtagama daripada Babad Tanah Jawi. Sumber berupa sastra babad, dari beberapa segi dinilai jatuh merosot secara tajam dibanding dengan sumber sastra lainnya. Namun demikian bukan berarti sumber tersebut tidak dapat dipercaya sepenuhnya, sebab bagaimanapun juga sumber itu masih menyimpan 
kesan-kesan peristiwa sejarah masa lampau, meskipun sudah kabur dan kacau dalam pengungkapannya. 6 Hoesein Djajadiningrat telah membuktikan hal itu, apapun uraiannya "local tradition" tidak dapat diabaikan begitu saja sebagai sumber sejarah (Djajadiningrat, 1913). Kalaupun dijumpai adanya kesan pemutar-balikan fakta, justru itu sebenarnya letak permasalahnnya, sebab tentunya penulis babad tersebut memiliki misi-misi tersendiri.

Bertolak dari pandangan tersebut, maka sebagai implikasinya muncul pertanyaan mengapa Babad Tanah Jawi menampilkan citra buruk terhadap Majapahit yang jauh dengan citra yang dipersembahkan oleh Prapanca dalam kakawinnya ?. Jawaban atas pertanyaan di atas berkaitan dengan latar belakang tujuan pemunculan masing-masing karya sastra itu sendiri, di samping kedudukan pujangga atau kawi, penulis karya sastra tersebut. Zoetmulder beranggapan, bahwa kawi itu pada dasarnya "imam magi sastra" yang hidup mengabdi kepada raja melalui karyanya. Sedangkan kakawin tidak lain adalah merupakan silunglung bagi sang kawi, yaitu sesuatu kekuatan yang akan menyertainya dalam perjalanan menuju akherat. 7

Dengan demikian puja sastra Nagarakrtagama pada dasarnya memang dimaksudkan untuk memuja kejayaan Majapahit dan keluhuran Raja Hayam Wuruk yang sedang memegang tambuk pemerintahan (Slametmulyana, 1979:18-20). Hal ini berbeda dengan Babad Tanah Jawi yang menurut Berg dimaksudkan sebagai magi sastra untuk menambah sakti dinasti Mataram. Dengan sendirinya penulis Babad ini akan lebih cenderung menitikberatkan pada kepentingan Kerajaan Mataram daripada Majapahit.

Babad Tanah Jawi menurut Berg adalah kumpulan dari cerita tradisi yang telah diubah sedemikian rupa dan diberinya cap untuk tujuan magi sastra guna menambah kebahagiaan raja dan kerajaan (Ibid., 91). Penulis Babad Tanah Jawi ingin menjadikan Mataram sebagai pusat kerajaan, oleh karena itu tidak merasa perlu menggambarkan Majapahit yang agung seperti diuraikan dalam Nagarakitagama. Bagi penulis babad ini, Majapahit cukup digambarkan sebagai kerajaan yang sementara atau tidak tetap.

Sebetulnya penulis babad ini sudah pasti mengenal cerita-cerita sejarah Jawa Timur tentang kebesaran Majapahit, tetapi agaknya hal itu tidak berarti untuk ditampilkan, karena tidak sesuai dengan tujuannya. Bahkan penggambaran kemegahan Majapahit, dipandang bisa mengurangi keagungan Kerajaan Mataram. Selain itu, perbedaan 
kekuasaan antara Majapahit dan Mataram juga merupakan faktor penting penyebab perbedaan citra penggambaran tersebut. Majapahit menurut Nagarakrtagama telah menguasai Nusantara sebaliknya Mataram dalam pertengahan pertama abad ke-17 baru merupakan sebuah negara yang sedang berkembang dan dalam akhir abad ke-17 sudah menjadi negara yang mulai retak. Dalam kondisi semacam inilah, penulis Babad Tanah Jawi ingin meningkatkan citra kerajaan terbesar di Jawa.

Babad Tanah Jawi lebih suka memilih penggambaran masa akhir Majapahit yang suram daripada menampilkan masa-masa kejayaan pada sekitar abad ke-16 M. Bahkan raja Majapahit akhir ditegaskan sebagai raja yang lemah dan berpenyakit kotor. Meskipun demikian, secara lebih jauh dalam babad ini ditekankan tentang kesembuhan penyakit baginda setelah memperistri gadis Wandan. Keturunan gadis Wandan inilah yang pada akhirnya menjadi raja-raja Mataram. Dengan demikian, secara sah Mataram merupakan kelanjutan Majapahit yang berhak menguasai tanah Jawa. Di sini letak mata-rantai dari garis keturunan Majapahit dan Mataram. Bagaimanapun juga versi Babad Tanah Jawi cukup mengagumkan yaitu cara penulis yang sangat cerdik dan ulung dalam bidangnya membelokkan jalannya sejarah.

Dengan demikian tampak adanya suatu paradoks dalam penulisan Babad Tanah Jawi, di satu pihak raja-raja Mataram menyatakan diri sebagai pewaris sah Majapahit, tetapi di lain sisi Majapahit digambarkan sebagai kerajaan tanpa kekuasaan yang besar.

\section{IV}

Berdasarkan uraian di atas dapatlah disimpulkan, bahwa kedudukan penulis sastra selaku pujangga keraton tidak dapat leluasa mengungkapkan pengalamannya, bahkan selalu terikat pada suatu tujuan tertentu yang berkaitan dengan eksistensi raja yang memerintah. Kakawin Nagarakrtagama maupun Babad Tanah Jawi adalah sebuah karya yang memang diabdikan kepada pemujaan raja atau dinasti untuk mendapatkan pengaruh gaib tertentu yang dapat menciptakan kebahagiaan raja dan seluruh rakyatnya.

Dengan demikian, sudah sewajarnya kalau masing-masing pujangga yang memberikan sumbangan melalui karyanya, akan cenderung berpegang pada masing-masing tujuan. Dalam hal ini Nagarakrtagama dimaksudkan untuk kepentingan "magi sastra" 
Majapahit, sedangkan Babad Tanah Jawi bertujuan demi kesaktian dinasti Mataram. Kedua karya sastra tersebut memiliki persamaan tujuan, yaitu bermaksud menciptakan karya "puja sastra". Perbedaannya, dalam Nagarakitagama pujangga Prapanca memuja secara tegas dan langsung kepada raja yang memerintah saat itu, sebaliknya penulis Babad Tanah Jawi melalui cara yang tidak kentara dan kurang langsung.

Pemujaan langsung Prapanca kepada Raja Rajasanagara tersebut, disampaikan terang-terangan. Hal tersebut dimaksudkan sebagai alat untuk lebih memperkuat pengaruh gaibnya. Sebaliknya dalam Babad Tanah Jawi, raja yang berkuasa di Mataram dipandang dari jarak dan waktu yang jauh oleh pujangga tersebut, sehingga memberi kesan, bahwa semua peristiwa itu sudah lama berlangsung.

\section{CATATAN :}

1. Kebesaran masa lampau Jawa dengan titik tolak kerajaan Majapahit, merupakan tema menarik yang sangat digemari oleh para penulis kreatif sebelum tahun 1950-an. Tulisan-tulisan tersebut membawa dampak besar, karena sebagian besar negarawan kita beranggapan Majapahit sebagai lambang kebesaran Indonesia masa silam. Selain itu sebagai alat untuk menggugah kesadaran guna kepentingan Nasionalisme. Kebanggaan terhadap Kerajaan Majapahit ini antara lain tercermin pada penggunaan "Bhinneka Tunggal Ika" - suatu ungkapan dari kutiban kakawin Sutasoma, sebuah karya yang ditulis beberapa tahun setelah Negarakrtagama - sebagai motto Republik Indonesia.

2. Lihat tentang uraian mengenai daerah-daerah di luar Pulau Jawa dalam Negarakrtagama pupuh XII:1 sampai pupuh XVI:5.

3. Periksa: Negarakrtagama, XV:1. Negara-negara tetangga di Asia Tenggara itu pada masa Hayamwuruk merupakan daerah-daerah yang dilindungi oleh raja Majapahit. Pembahasan hubungan Majapahit dengan negara-negara lain di Asia Tenggara dapat dilihat dalam a.I. Elizabeth L. Hassel, "the Sri-Vijayan and Majapahit Empires and the Theory of their Political Association whith the Philippines", Philippine Social Science and Humanities Review. XVIII (1): 1953.

4. Wilayah kekuasaan Majapahit pernah menjadi bahan perdebatan di antara para ahli. Prof. Dr. C.C. Berg misalnya beranggapan bahwa wilayah Kerajaan Majapahit sebenarnya tidak pernah memiliki 
wilayah yang luasnya kurang lebih sama dengan luas wilayah Indonesia sekarang. Lebih jauh sarjana ini menghubungkan daerah-daerah pengaruh Majapahit di luar Pulau Jawa itu dengan pengertian "catur prakerti" dari filsafat Budhisme, sehingga menurut Berg pengertian Nusantara tersebut hanya suatu cita-cita saja, bukan dalam arti yang sebenarnya (Berg, 1950-1951:481-520). Dengan kata lain Berg beranggapan kebesaran Majapahit dalam Nagarakitagama itu adalah Majapahitnya Prapanca. Reaksi terhadap tulisan Berg tersebut, kebanyakan orang Indonesia saat itu, apalagi bagi mereka yang sedang kagum dan menekuni diri dengan masa silamnya, adalah sikap berang. Banyak yang menuding tulisan Berg -- yang terbit segera setelah Indonesia merdeka -- ditulis karena rasa dendam terhadap republik yang baru lahir itu. Namun lepas dari pro dan kontra dari kilah ilmiah para sarjana terdahulu, serangkaian data dapat dijadikan bukti. Majapahit saat itu memang kerajaan terbesar yang sangat berpengaruh setidaknya pengaruh kultural. Kerajaan ini telah berhasil menegakkan kesatuan politik yang luas dan tidak tertandingi oleh kerajaankerajaan sebelumnya (Kartodirdjo, 1982).

5. Menurut Brandes, Babad Tanah Jawi disusun berdasarkan Serat Kanda sekitar tahun 1700 M., sedangkan menurut Hoesein Djajadiningrat Babad Tanah jawi ditulis selambat-lambatnya pada tahun 1623 M. (Brandes, 1920; Hoesein, 1913).

6. Tentang hal ini lihat Soepomo Surjohudojo, "Tugas Penulis Babad", Laporan KIPN-II, VI, 1965: 9-36.

7. Kata Silinglung ini sering dipakai dalam kaitannya dengan seorang yang telah meninggal dunia, sehingga silunglung berarti sesuatu yang menemani jiwa dalam perjalan ke dunia sana, seperti misalnya pahala, atau juga senjata bagi seorang ksatria dan kakawin bagi seorang kawi. 


\section{KEPUSTAKAAN}

Berg, C.C. , 1974, Penulisan Sejarah Jawa, Seri terjemahan KITLV LIPI, Jakarta: Bratara.

Darmono, Supardi Joko, 1974, Sosiologi Sebuah Pengantar Ringkas, Jakarta: Pusat Pembinaan dan Pengembangan Bahasa Departemen Pendidikan dan Kebudayaan.

Djafar, Hasan., 1978, Girindrawardhana Beberapa Masalah Majapahit Akhir, Jakarta: Departemen Pendidikan dan Kebudayaan.

Djajadiningrat, P.A Hoesein., 1965, Local Traditions and the Study of indonesian History, di dalam: Soedjatmoko., Introduction to Indonesian Historiography, New York: Canel University Press.

Kartodirdjo, Sartono., 1982, Pemikiran dan Perkembangan Historiografi Indonesia, Suatu Alternatif, Jakarta: Gramedia.

Mulyana, Slamet., 1979, Nagarakrtagama dan Tafsir Sejarahnya, Jakarta: Bhratara.

Olthof, WL., 1941, PoenikaSerat Babad Tanah Djawi Wiwit Saking Nabi Adam Doemoegi Ing Tahoen 1647, 's-Gravenhage Nij-Hoff.

Pigeud, Th.G.Th., 1960-1963, Java in the Foerteenh Century: A Study in Cultural History, The Negarakrtagama by Rakawi Prapanca of Majapahit, 1365 A.D. The Hague, Martinus Nijhoff, 5 vols (Vol. I, 1960: vol. II, 1960; vol. III, 1960; vol. IV, 1962; vol V, 1963).

Poerbatjaraka, R.M.Ng., 1957, Kepustakaan Djawa, Djakarta: Djambatan, cetakan kedua.

Schirieke, B.J.O., 1957, Indonesian Sociological Studies, Part Two: Ruler and Realm in Early Java, The Hague, Bandung, W. van Hoeve.

Zoetmulder, P.J., 1983, Kalangwan, Sastra Jawa Kuna Selayang

Pandang, Terjemahan oleh Dick Hartoko, Jakarta: Djambatan. 